\title{
Benzo-containing cage-annulated crown ethers: a new class of $\operatorname{Ag}(\mathrm{I})$ complexants
}

\author{
Alan P. Marchand*, Huiguo Lai, Bo-Liang Deng, and José Calderón \\ Department of Chemistry, University of North Texas, Denton, Texas 76203-5070 \\ E-mail: alan_marchand@sbcglobal.net
}

Dedicated to Professor Lubor Fisera on the occasion of his $60^{\text {th }}$ birthday

(received 26 Jan 04; accepted 23 Apr 04; published on the web 24 June 04)

\begin{abstract}
Six novel cage-annulated crown ethers, 1-6, that contain 1,2-, 1,3- and 1,4-disubstituted benzene moieties have been prepared. The results of alkali metal picrate extraction experiments performed by using 1-6 as host systems generally are in accord with expectations based upon consideration of the familiar size-fit principle. None of these compounds area particularly avid alkali metal cation complexants; in addition, they display only moderate selectivity in their binding properties toward alkali metal cations. The ability of 1-6 to function as $\operatorname{Ag}(\mathrm{I})$ complexants has been assessed via silver picrate extraction experiments and by flame atomic absorption spectrophotometry (FAAS). Compound 4, and to a somewhat lesser extent compounds 6, 3, and 2, proved to be the most avid $\operatorname{Ag}(\mathrm{I})$ complexants among the six host systems studied.
\end{abstract}

Keywords: Benzocrown ethers, selective cation complexation, alkali metal picrate extraction, atomic absorption

\section{Introduction}

In recent years, our interests have turned toward the synthesis and chemistry of novel, cageannulated crown ethers that serve as host molecules for selective complexation and transport of cationic species. ${ }^{1}$ Systems of this type have found application to environmental remediation through, e.g., selective separation of $\mathrm{NaOH}$ from radioactive tank wastes that employ synergistic pseudo hydroxide extraction techniques. ${ }^{2}$ In addition, optically active cage-annulated crown ethers have been used as new agents for enantioselective recognition and transport of chiral ammonium salts. ${ }^{3}$ 
Effective measures are being sought to promote effective complexation and transport of $\operatorname{Ag}(\mathrm{I})^{4}$ with particular application to environmental remediation of $\mathrm{Ag}(\mathrm{I})$-contaminated natural waters. $^{5}$ In this connection, benzo-annulated crown ethers have been shown to function effectively as $\operatorname{Ag}(\mathrm{I})$ complexants. Thus, X-ray crystallographic analysis of dinuclear $\operatorname{Ag}(\mathrm{I})$ complexes with dibenzo-18-crown-6 reveal that the guest $\mathrm{Ag}(\mathrm{I})$ cations interact with the hard donor oxygen atoms in the crown ether and with the soft donor benzene rings via a stabilizing $\eta^{2}$ cation- $\pi$ interaction. 6

Pursuant to this observation 6 and to results obtained from other recent collaborative studies designed to assess the ability of cage-annulated crown ethers to function effectively as $\operatorname{Ag}(\mathrm{I})$ complexants, ${ }^{7}$ we now report the synthesis of six new cage-annulated crown ethers, i.e., 1-6 (Figure 1), that incorporate 1,2-, 1,3-, or 1,4-disubstituted benzene moieties into the coronand structure. The ability of the resulting crown ethers to function effectively as $\mathrm{Ag}(\mathrm{I})$ complexants has been evaluated via $\mathrm{Ag}(\mathrm{I})$ picrate liquid-liquid extraction studies and by application of flame atomic absoprtion spectrophotometry (FAAS). In hosts 5 and $\mathbf{6}$, site-specific introduction of $\mathrm{Br}$ into the benzene ring was performed in the hope that the resulting functionalized aromatic ring might provide an additional soft ligand site for coordination to $\mathrm{Ag}(\mathrm{I})$ in the host-guest complex.

\section{Results and Discussion}

Syntheses of host molecules. The procedures employed to prepare hosts 1-4 are summarized in Scheme 1. In each case, base promoted, metal cation templated $\mathrm{S}_{\mathrm{N}} 2$ displace-ments of OTs by phenolate anions were employed to prepare the coronands of interest. Thus, base promoted reactions of cage-annulated podands $\mathbf{8}^{8}$ and $\mathbf{9}^{9}$ with phenol-containing podands $7^{10}$ and $\mathbf{1 0}^{11}$ performed by using the approach shown in Scheme 1 afforded host systems 1-4, respectively. 

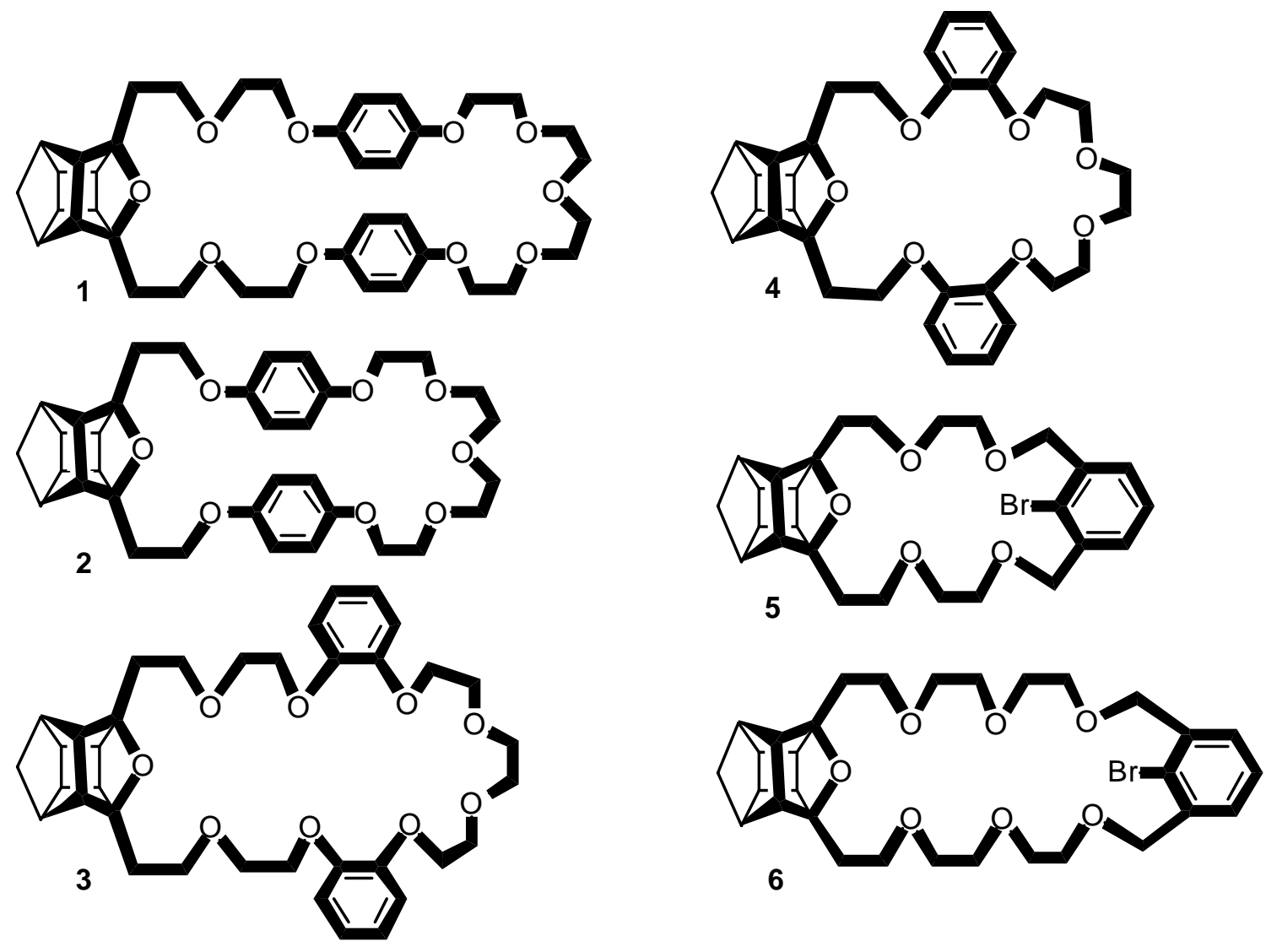

Figure 1. Cage-annulated crown ethers prepared in this study and used as Ag(I) complexants.

A similar metal cation template approach was used to prepare host systems $\mathbf{5}$ and $\mathbf{6}$, as shown in Scheme 2. Here, the anions derived from cage-annulated podands $12^{8}$ and $14^{12}$ were used to displace halogen from $11^{13}$ and 13, respectively to form host systems 5 and $\mathbf{6}$, respectively (Scheme 2). 

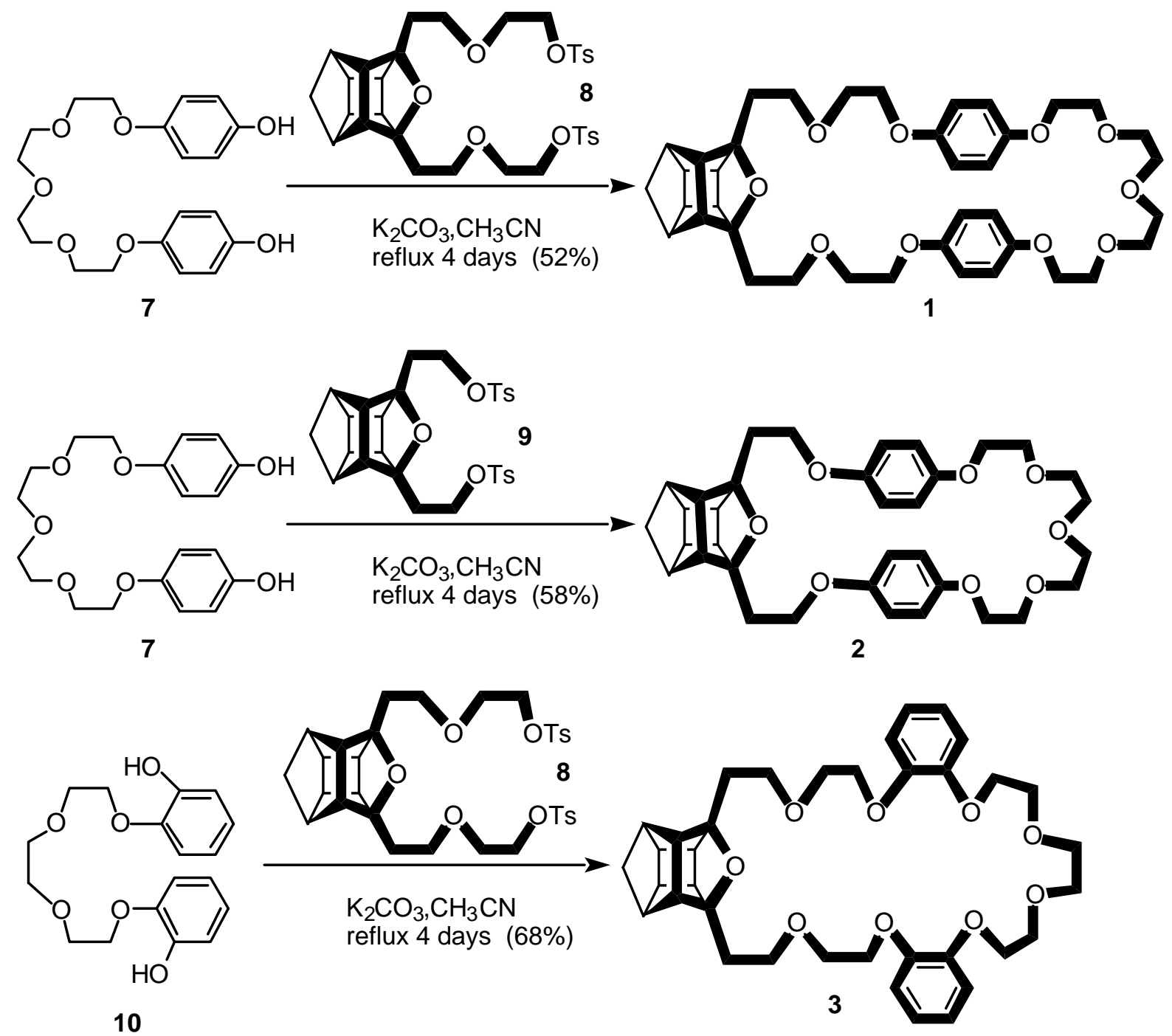

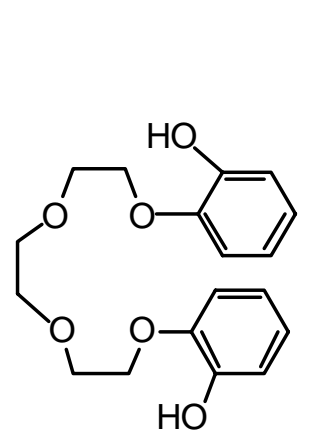

10

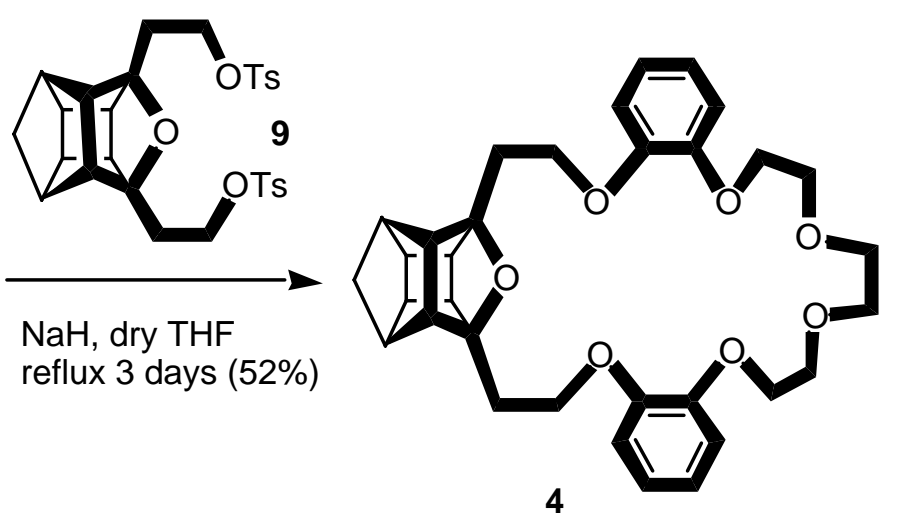

Scheme 1 

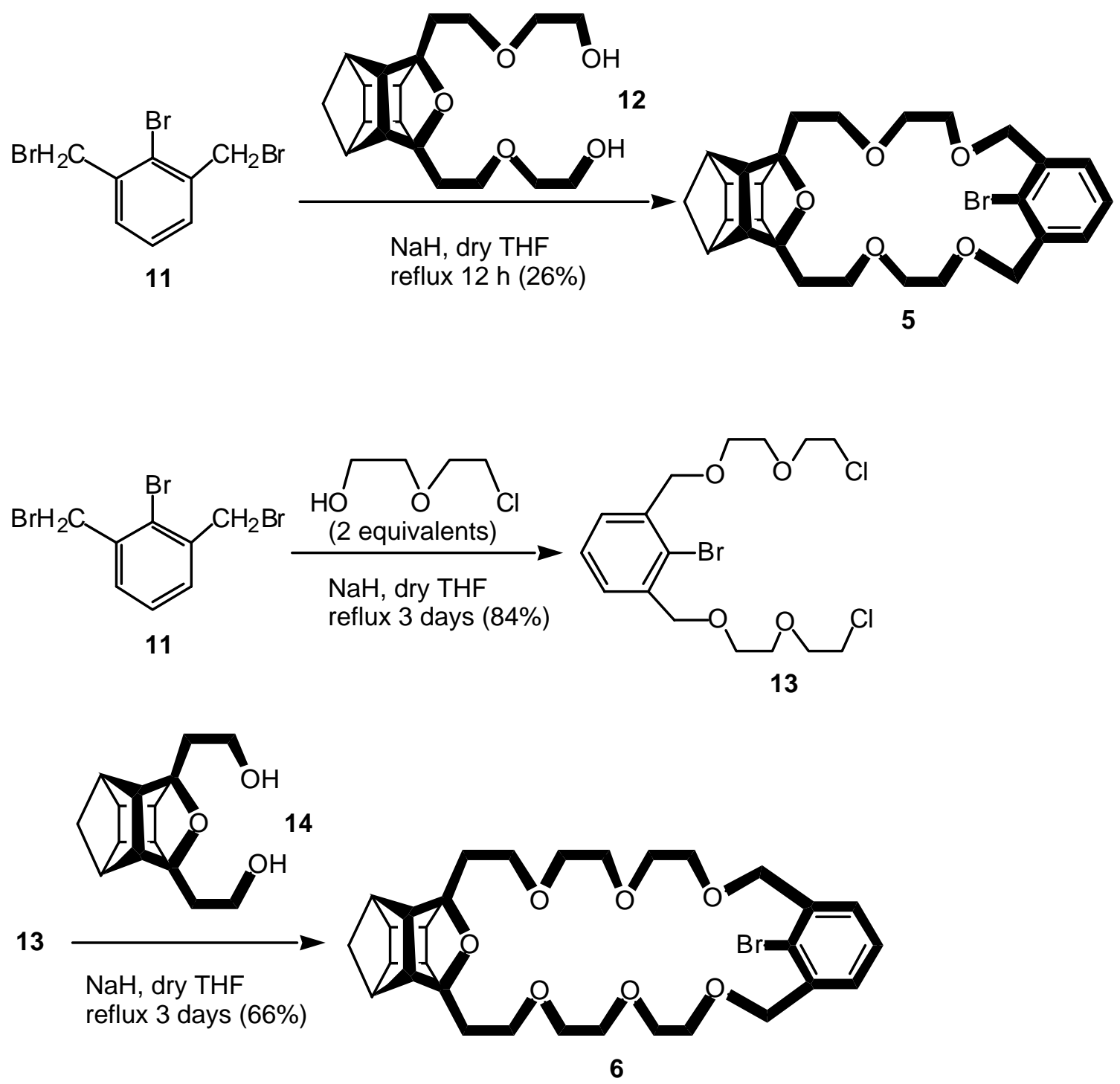

\section{Scheme 2}

Results of picrate extraction experiments. The procedure used to perform liquid-liquid metal picrate extractions has been described previously. ${ }^{12}$ The results obtained by using 1-6 as hosts for extractions of alkali metal picrates and $\mathrm{Ag}(\mathrm{I})$ picrate from aqueous solutions into $\mathrm{CHCl}_{3}$ are summarized in Table 1. 
Table 1. Results of picrate extraction experiments

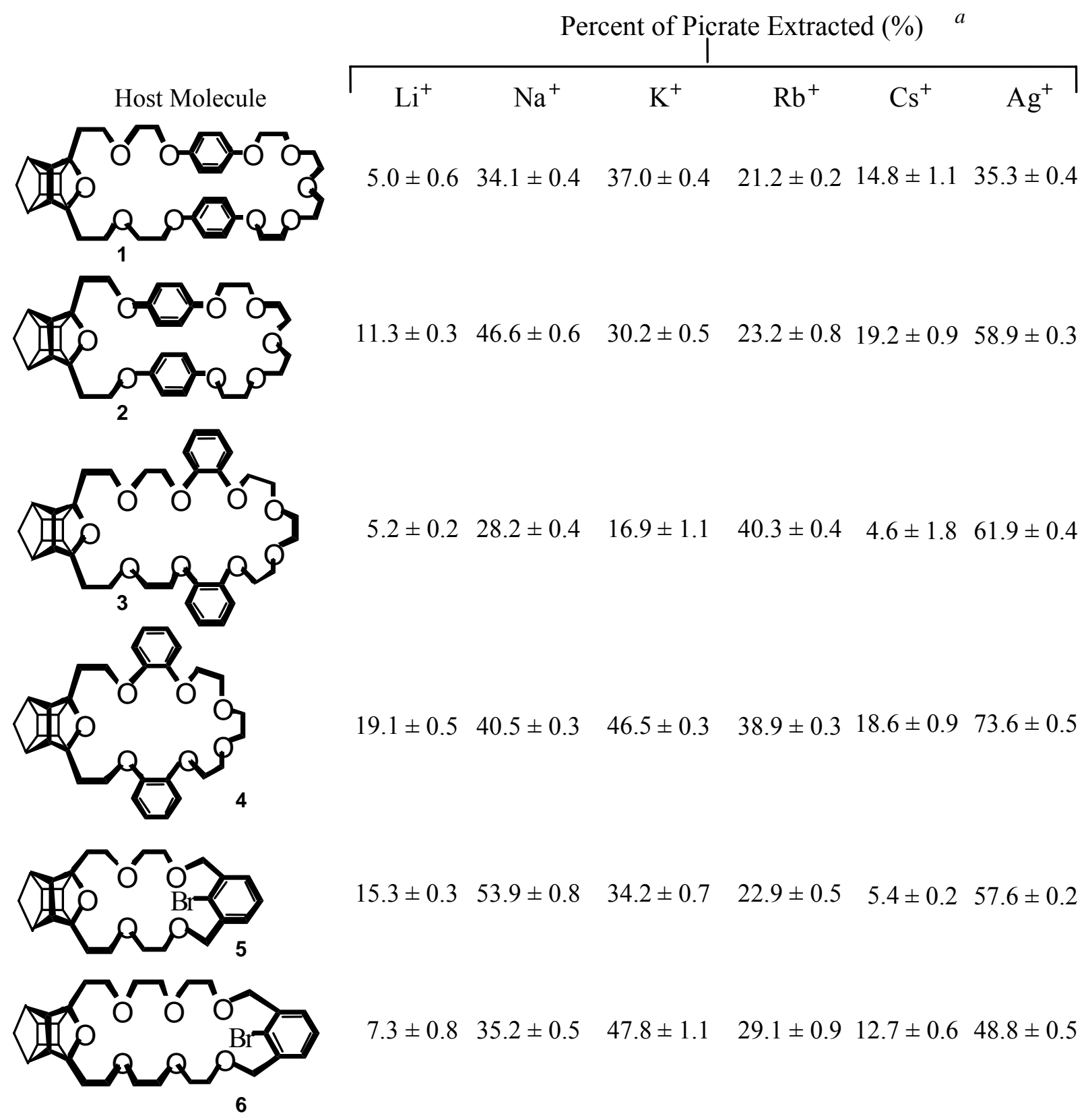

${ }^{a}$ Averages and standard deviations calculated for data obtained from four independent extraction experiments; see reference 12 .

Certain trends become evident upon inspection of the data contained in Table 1. Host systems 1-4, which contain 1,2- or 1,4-disubstituted benzene moieties, are not particularly avid hosts toward alkali metal cations. In addition, with the exclusion of the guest "size extremes" (i.e., $\mathrm{Li}^{+}$and $\mathrm{Cs}^{+}$), these four hosts display relatively little selectivity in their binding properties 
toward alkali metal cations. Those hosts that possess smaller cavities, i.e., 2 and 4, show a slight preference for binding to $\mathrm{Na}^{+}$and $\mathrm{K}^{+}$, respectively, while those with larger cavity sizes, i.e., 1 and $\mathbf{3}$, display a slight preference for binding to $\mathrm{K}^{+}$and $\mathrm{Rb}^{+}$, respectively. Similarly, $\mathbf{5}$ functions as a somewhat selective $\mathrm{Na}^{+}$complexant, while 6, which possesses larger cavity dimensions, binds preferentially to $\mathrm{K}^{+}$. These results generally are in accord with expectations based upon consideration of the familiar size-fit principle. ${ }^{14}$

Interestingly, several of the host systems, particularly 2-5, proved to be relatively avid $\mathrm{Ag}^{+}$ compexants. Most likely, this behavior results from a combination of factors that include cavity size and shape ${ }^{14}$ and also the presence of electron-rich aromatic rings that can function effectively as $\pi$-donors. ${ }^{4,7}$

Results of FAAS experiments. The procedure that was employed to perform FAAS measurements is described in the Experimental Section (vide infra). ${ }^{15}$ In Table 2, the results thereby obtained are compared with the corresponding results obtained via silver picrate extraction experiments. In general, we observe good qualitative agreement between the results obtained by using these two different analytical methods. The most striking exceptions to this statement are noted when 5 and $\mathbf{6}$ were employed as $\mathrm{Ag}^{+}$complexants. Indeed, the results obtained from FAAS experiments suggest that the ability of $\mathbf{5}$ and $\mathbf{6}$ to serve as $\mathrm{Ag}^{+}$complexants should be similar to that shown by $\mathbf{1}$ and 2 , respectively. By way of contrast, the picrate extraction results suggest that $\mathbf{5}$ is a somewhat more effective $\mathrm{Ag}^{+}$complexant than $\mathbf{1}$, whereas $\mathbf{2}$ is more effective than $\mathbf{6}$ in this regard.

Summary and conclusions. Six new cage-annulated crown ethers, 1-6 have been prepared, and their ability to function as alkali metal cation complexants and as $\mathrm{Ag}^{+}$complexants has been assessed via application of two independent analytical methods. The results of alkali metal picrate extraction experiments with 1-6 as host systems appear generally to follow the size-fit principle. Among the six host systems included in this study, 4 proved to be the most effective $\mathrm{Ag}^{+}$complexant. 
Table 2. Results of FAAS experiments ${ }^{a}$

Host Molecule
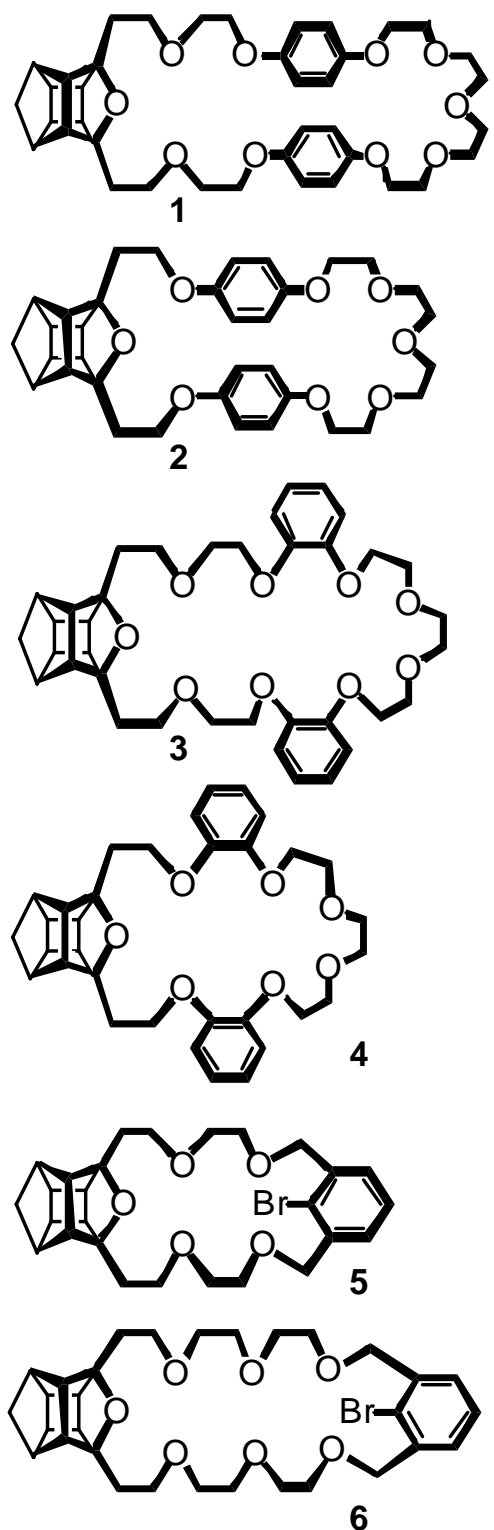

Results obtained via $\mathrm{Ag}+$

FAAS studies (\%)

$46.5 \pm 2.5$

$63.2 \pm 1.8$

$73.1 \pm 1.9$

$86.3 \pm 2.1$

$44.3 \pm 1.6$

$68.2 \pm 2.7$
Results obtained via $\mathrm{Ag}+$

picrate extraction studies (\%)
$35.3 \pm 0.4$

$58.9 \pm 0.3$

$61.9 \pm 0.4$

$57.6 \pm 0.2$

$48.8 \pm 0.5$

${ }^{a}$ Averages and standard deviations calculated for data obtained from four independent extraction experiments. Ten absorbance measurements were obtained for each sample

The ability of 1-6 to function as $\operatorname{Ag}(\mathrm{I})$ complexants has been assessed via silver picrate extraction experiments and by flame atomic absorption spectrophotometry (FAAS). In general, we observe good qualitative agreement among the results obtained by using these two different analytical methods. 
The data in Table 2 suggest that the ability of coronand 5 to function as an $\mathrm{Ag}^{+}$complexant is similar to that of host systems $\mathbf{1}$ and 2, both of which possess significantly larger cavity dimensions. This result suggests that the presence of $\mathrm{Br}$ as a soft Lewis base substituent may indeed contribute somewhat to overall stabilization of the resulting $5 \cdot \mathrm{Ag}^{+}$complex.

\section{Experimental Section}

General Procedures. Melting points are uncorrected. High-resolution mass spectral data reported herein were obtained by Professor Jennifer S. Brodbelt at the Mass Spectrometry Facility at the Department of Chemistry and Biochemistry, University of Texas at Austin by using a ZAB-E double sector high resolution mass spectrometer (Micromass, Manchester, England) that was operated in chemical ionization mode. Elemental microanalyses were performed by personnel at M-H-W Laboratories, Pheonix, AZ.

Synthesis of a cage-annulated crown ether (1). A suspension of $7^{10}(658 \mathrm{mg}, 1.74 \mathrm{mmol}), \mathbf{8}^{8}$ (1.12 g, $1.74 \mathrm{mmol}), \mathrm{KI}(664 \mathrm{mg}, 4.0 \mathrm{mmol})$, and $\mathrm{K}_{2} \mathrm{CO}_{3}(2.76 \mathrm{~g}, 20 \mathrm{mmol})$ in $\mathrm{CH}_{3} \mathrm{CN}(40 \mathrm{~mL})$ was refluxed during 4 days. The reaction mixture was allowed to cool gradually to ambient temperature and then was filtered. The residue was washed with $\mathrm{CH}_{3} \mathrm{CN}(2 \times 50 \mathrm{~mL})$. The combined filtrates were concentrated in vacuo, and $\mathrm{CH}_{2} \mathrm{Cl}_{2}(150 \mathrm{~mL})$ was added to the residue. The resulting solution was washed sequentially with water $(3 \times 50 \mathrm{~mL})$ and brine $(3 \times 50 \mathrm{~mL})$, dried $\left(\mathrm{MgSO}_{4}\right)$ and filtered, and the filtrate was concentrated in vacuo. The residue was purified via column chromatography on silica gel by eluting with 50\% EtOAc-hexane. Pure 1 (604 mg, 52\%) was thereby obtained as a colorless viscous oil; IR (film) 2932 (s), 2870 (s), 1509 (s), 1545 (s), 1539 (m), 1229 (s), 1129 (s), 1065 (s), 929 (s), 896 (m), 828 (s), $755 \mathrm{~cm}^{-1}$ (m); ${ }^{1} \mathrm{H}$ $\operatorname{NMR}\left(\mathrm{CDCl}_{3}\right) \delta 1.44\left(\mathrm{AB}, J_{\mathrm{AB}}=10.3 \mathrm{~Hz}, 1 \mathrm{H}\right), 1.78\left(\mathrm{AB}, J_{\mathrm{AB}}=10.3 \mathrm{~Hz}, 1 \mathrm{H}\right), 2.01-2.52(\mathrm{~m}$, $8 \mathrm{H}), 3.58-3.81(\mathrm{~m}, 22 \mathrm{H}), 3.98-4.04(\mathrm{~m}, 10 \mathrm{H}), 6.77-6.80(\mathrm{~m}, 8 \mathrm{H}) ;{ }^{13} \mathrm{C} \mathrm{NMR}\left(\mathrm{CDCl}_{3}\right) \delta$ $32.6(\mathrm{t}), 42.8(\mathrm{~d}), 43.4(\mathrm{t}), 44.4(\mathrm{~d}), 48.4(\mathrm{~d}), 58.8(\mathrm{~d}), 68.1(\mathrm{t}), 68.2(\mathrm{t}), 69.1(\mathrm{t}), 69.7(\mathrm{t}), 69.8(\mathrm{t})$, $70.8(\mathrm{t}), 94.5(\mathrm{~s}), 115.5(\mathrm{~d}), 115.6(\mathrm{~d}), 153.0(\mathrm{~s}), 153.1(\mathrm{~s})$. Exact mass (CI-HRMS) Calcd for $\mathrm{C}_{39} \mathrm{H}_{50} \mathrm{O}_{10}:\left[M_{\mathrm{r}}+\mathrm{H}\right]^{+} \mathrm{m} / \mathrm{z} 679.3404$. Found: $\left[M_{\mathrm{r}}+\mathrm{H}\right]^{+} \mathrm{m} / \mathrm{z} 679.3484$.

Synthesis of a cage-annulated crown ether (2). A suspension of $7^{10}$ (493 mg, $\left.1.3 \mathrm{mmol}\right), 9^{9}$ (726 mg, $1.3 \mathrm{mmol}$ ), and $\mathrm{K}_{2} \mathrm{CO}_{3}(3.64 \mathrm{~g}, 37.3 \mathrm{mmol})$ in $\mathrm{CH}_{3} \mathrm{CN}(80 \mathrm{~mL}$ ) was refluxed during 4 days. The reaction mixture was allowed to cool gradually to ambient temperature and then was filtered. The residue was washed with $\mathrm{CH}_{3} \mathrm{CN}(2 \times 50 \mathrm{~mL})$. The combined filtrates were concentrated in vacuo, and $\mathrm{CH}_{2} \mathrm{Cl}_{2}(150 \mathrm{~mL})$ was added to the residue. The resulting solution was washed sequentially with water $(3 \times 50 \mathrm{~mL})$ and brine $(3 \times 50 \mathrm{~mL})$, dried $\left(\mathrm{MgSO}_{4}\right)$ and filtered, and the filtrate was concentrated in vacuo. The residue was purified via column chromatography on silica gel by eluting with 50\% EtOAc-hexane. Pure 2 (446 mg, 58\%) was thereby obtained as a colorless viscous oil; IR (film) 2953 (s), 2870 (s), 1596 (w), 1508 (s), 1470 (m), 1360 (s), 1234 (s), 1132 (s), 1067 (s), 824 (s), $751 \mathrm{~cm}^{-1}$ (m); ${ }^{1} \mathrm{H} \mathrm{NMR}\left(\mathrm{CDCl}_{3}\right) \delta 1.50$ 
$\left(\mathrm{AB}, J_{\mathrm{AB}}=9.6 \mathrm{~Hz}, 1 \mathrm{H}\right), 1.85\left(\mathrm{AB}, J_{\mathrm{AB}}=9.6 \mathrm{~Hz}, 1 \mathrm{H}\right), 2.12-2.20(\mathrm{~m}, 4 \mathrm{H}), 2.40(\mathrm{~s}, 2 \mathrm{H}), 2.59$ $(\mathrm{s}, 6 \mathrm{H}), 3.87(\mathrm{~s}, 8 \mathrm{H}), 3.81(\mathrm{t}, J=4.5 \mathrm{~Hz}, 4 \mathrm{H}), 3.96-4.07(\mathrm{~m}, 8 \mathrm{H}), 6.73-6.78(\mathrm{~m}, 8 \mathrm{H}) ;{ }^{13} \mathrm{C}$ NMR $\left(\mathrm{CDCl}_{3}\right) \delta 32.5(\mathrm{t}), 41.2(\mathrm{~d}), 43.4(\mathrm{t}), 43.7(\mathrm{~d}), 48.1(\mathrm{~d}), 58.9(\mathrm{~d}), 66.2(\mathrm{t}), 67.9(\mathrm{t}), 69.5(\mathrm{t})$, $70.4(\mathrm{t}), 70.6(\mathrm{t}), 94.1$ (s), 115.2 (d), 115.7 (d), 152.7 (s), 153.3 (s). Exact mass (CI-HRMS) Calcd for $\mathrm{C}_{35} \mathrm{H}_{42} \mathrm{O}_{8}:\left[M_{\mathrm{r}}+\mathrm{H}\right]^{+} \mathrm{m} / \mathrm{z}$ 591.2958. Found: $\left[M_{\mathrm{r}}+\mathrm{H}\right]^{+} \mathrm{m} / \mathrm{z} 591.2950$.

Synthesis of a cage-annulated crown ether (3). A suspension of $\mathbf{8}^{8}(849 \mathrm{mg}, 1.32 \mathrm{mmol}), \mathbf{1 0}^{11}$ (440 mg, $1.32 \mathrm{mmol})$, and $\mathrm{K}_{2} \mathrm{CO}_{3}(3.20 \mathrm{~g}$, $23.5 \mathrm{mmol})$ in $\mathrm{CH}_{3} \mathrm{CN}(60.0 \mathrm{~mL})$ was refluxed during 4 days. The reaction mixture was allowed to cool gradually to ambient temperature and then was filtered. The residue was washed with $\mathrm{CH}_{3} \mathrm{CN}(2 \times 50 \mathrm{~mL})$. The combined filtrates were concentrated in vacuo, and $\mathrm{CH}_{2} \mathrm{Cl}_{2}(150 \mathrm{~mL})$ was added to the residue. The resulting solution was washed sequentially with water $(3 \times 50 \mathrm{~mL})$ and brine $(3 \times 50 \mathrm{~mL})$, dried $\left(\mathrm{MgSO}_{4}\right)$ and filtered, and the filtrate was concentrated in vacuo. The residue was purified via column chromatography on silica gel by eluting with 50\% EtOAc-hexane. Pure 3 (568 mg, 68\%) was thereby obtained as a colorless viscous oil; IR (film) 2939 (s), 2862 (s), 1591 (s), 1500 (s), 1453 (s), 1362 (m), 1328 (m), 1255 (m), 1117 (m), 1053 (s), 925 (m), $740 \mathrm{~cm}^{-1}(\mathrm{~m}) ;{ }^{1} \mathrm{H}$ NMR $\left(\mathrm{CDCl}_{3}\right) \delta 1.44\left(\mathrm{AB}, J_{\mathrm{AB}}=10.3 \mathrm{~Hz}, 1 \mathrm{H}\right), 1.80\left(\mathrm{AB}, J_{\mathrm{AB}}=10.3 \mathrm{~Hz}, 1 \mathrm{H}\right), 2.01-2.11(\mathrm{~m}, 4 \mathrm{H})$, 2.35 (s, $2 \mathrm{H}), 2.47-2.54$ (m, $6 \mathrm{H}), 3.64-3.67$ (t, $J=7.26 \mathrm{~Hz}, 4 \mathrm{H}), 3.77-3.90$ (m, $12 \mathrm{H}), 4.09-4.18$ $(\mathrm{m}, 8 \mathrm{H}), 6.83-6.90(\mathrm{~m}, 8 \mathrm{H}) ;{ }^{13} \mathrm{C} \mathrm{NMR}\left(\mathrm{CDCl}_{3}\right) \delta 32.7(\mathrm{t}), 41.7(\mathrm{~d}), 43.4(\mathrm{t}), 44.3(\mathrm{~d}), 48.2(\mathrm{~d})$, $58.9(\mathrm{~d}), 68.6(\mathrm{t}), 69.1(\mathrm{t}), 69.4(\mathrm{t}), 69.7(\mathrm{t}), 70.9(\mathrm{t}), 94.2(\mathrm{~s}), 114.0(\mathrm{~d}), 114.8(\mathrm{~d}), 121.3(\mathrm{~d})$, 121.5 (d), 148.9 (s), 149.2 (s). Exact mass (CI-HRMS) Calcd for $\mathrm{C}_{37} \mathrm{H}_{46} \mathrm{O}_{9}:\left[M_{\mathrm{r}}+\mathrm{H}\right]^{+} \mathrm{m} / \mathrm{z}$ 635.32201. Found: $\left[M_{\mathrm{r}}+\mathrm{H}\right]^{+} \mathrm{m} / \mathrm{z} 635.32210$.

Synthesis of a cage-annulated crown ether (4). A suspension of $\mathbf{9}^{9}$ (556 mg, $\left.1.0 \mathrm{mmol}\right), \mathbf{1 0}^{11}$ (334 mg, $1.0 \mathrm{mmol})$, and $\mathrm{K}_{2} \mathrm{CO}_{3}(2.72 \mathrm{~g}, 20.0 \mathrm{mmol})$ in $\mathrm{CH}_{3} \mathrm{CN}(50.0 \mathrm{~mL})$ was refluxed during 4 days. The reaction mixture was allowed to cool gradually to ambient temperature and then was filtered. The residue was washed with $\mathrm{CH}_{3} \mathrm{CN}(2 \times 50 \mathrm{~mL})$. The combined filtrates were concentrated in vacuo, and $\mathrm{CH}_{2} \mathrm{Cl}_{2}(150 \mathrm{~mL})$ was added to the residue. The resulting solution was washed sequentially with water $(3 \times 50 \mathrm{~mL})$ and brine $(3 \times 50 \mathrm{~mL})$, dried $\left(\mathrm{MgSO}_{4}\right)$ and filtered, and the filtrate was concentrated in vacuo. The residue was purified via column chromatography on silica gel by eluting with 50\% EtOAc-hexane. Pure 4 (284 mg, 52\%) was thereby obtained as a colorless microcrystalline solid: $\mathrm{mp} 49-50{ }^{\circ} \mathrm{C}$; IR (KBr) 2933 (s), 2871 (s), 1592 (s), 1499 (s), 1469 (s), 1389 (m), 1329 (m), 1113 (m), 1068 (m), 748 cm-1 (m); ${ }^{1} \mathrm{H}$ NMR $\left(\mathrm{CDCl}_{3}\right) \delta 1.32\left(\mathrm{AB}, J_{\mathrm{AB}}=10.3 \mathrm{~Hz}, 1 \mathrm{H}\right), 1.75\left(\mathrm{AB}, J_{\mathrm{AB}}=10.3 \mathrm{~Hz}, 1 \mathrm{H}\right), 2.17(\mathrm{~s}, 2 \mathrm{H}), 2.29-$ 2.41 (m, 4 H), 2.56 (s, 4 H), 2.99 (t, $J=3.6 \mathrm{~Hz}, 2 \mathrm{H}), 3.81$ (s, $4 \mathrm{H}), 3.93$ (t, $J=3.6 \mathrm{~Hz}, 4 \mathrm{H}$ ), 4.08-4.13 (m, $8 \mathrm{H}), 6.84(\mathrm{~m}, 8 \mathrm{H}) ;{ }^{13} \mathrm{C} \mathrm{NMR}\left(\mathrm{CDCl}_{3}\right) \delta 32.6(\mathrm{t}), 42.3(\mathrm{~d}), 43.4(\mathrm{t}), 44.9(\mathrm{~d}), 49.0$ (d), $59.5(\mathrm{~d}), 65.2(\mathrm{t}), 68.7(\mathrm{t}), 70.3(\mathrm{t}), 71.1(\mathrm{t}), 94.7(\mathrm{~s}), 112.1(\mathrm{~d}), 112.7$ (d), 120.5 (d), 121.0 (d), 148.5 (s), 148.7 (s). Anal. Calcd for $\mathrm{C}_{33} \mathrm{H}_{38} \mathrm{O}_{7}$ : C, 72.51; H, 7.01. Found: C, 72.36; H, 6.85.

Synthesis of cage-annulated crown ether (5). To a solution of $12^{8}(336 \mathrm{mg}, 1.0 \mathrm{mmol})$ in dry THF $(100 \mathrm{~mL})$ was added $\mathrm{NaH}(400 \mathrm{mg}, 60 \%$ dispersion in mineral oil, $10 \mathrm{mmol})$, and the resulting solution was refluxed under $\mathrm{N}_{2}$ during $3 \mathrm{~h}$. The reaction mixture then was allowed to 
cool gradually to ambient temperature. To the reaction mixture was added dropwise with stirring a solution of $11^{13}$ (343 mg, $\left.1.0 \mathrm{mmol}\right)$ in THF $(20 \mathrm{~mL})$ during 30 minutes, at which time the resulting mixture was refluxed during $12 \mathrm{~h}$. The reaction mixture was allowed to cool gradually to ambient temperature and water $(2.0 \mathrm{~mL})$ was added dropwise with stirring to quench the reaction. After the mixture had become clear, an additional quantity of water $(30 \mathrm{~mL})$ was added. The resulting mixture was extracted with EtOAc $(4 \times 50 \mathrm{~mL})$. The combined extracts were washed sequentially with water $(2 \times 30 \mathrm{~mL})$ and brine $(3 \times 30 \mathrm{~mL})$, dried $\left(\mathrm{Na}_{2} \mathrm{SO}_{4}\right)$ and filtered, and the filtrate was concentrated in vacuo. The residue was purified by column chromatography on silica gel by eluting with 30\% EtOAc-hexane. Pure 5 (134 mg, 26\%) was thereby obtained as a colorless microcrystalline solid: $\mathrm{mp} 90-91{ }^{\circ} \mathrm{C}$; IR (KBr) 2865 (s), 1455 (w), 1422 (w), $1357(\mathrm{~m}), 1292(\mathrm{w}), 1129(\mathrm{~s}), 1109(\mathrm{~s}), 1018(\mathrm{~m}), 796(\mathrm{~m}), 770 \mathrm{~cm}^{-1}(\mathrm{~m}) ;{ }^{1} \mathrm{H}$ NMR $\left(\mathrm{CDCl}_{3}\right) \delta$ $1.33\left(\mathrm{AB}, J_{\mathrm{AB}}=10.3 \mathrm{~Hz}, 1 \mathrm{H}\right), 3.21\left(\mathrm{AB}, J_{\mathrm{AB}}=10.3 \mathrm{~Hz}, 1 \mathrm{H}\right), 1.92(\mathrm{t}, J=6.2 \mathrm{~Hz}, 4 \mathrm{H}), 2.20$ (s, $2 \mathrm{H}), 2.30$ (s, $6 \mathrm{H}), 3.47$ (t, $J=6.2 \mathrm{~Hz}, 4 \mathrm{H}), 3.56-3.60(\mathrm{~m}, 4 \mathrm{H}), 3.69-3.73(\mathrm{~m}, 4 \mathrm{H}), 4.62$ (s, 4 $\mathrm{H}), 7.28-7.42(\mathrm{~m}, 3 \mathrm{H}) ;{ }^{13} \mathrm{C} \mathrm{NMR}\left(\mathrm{CDCl}_{3}\right) \delta 32.6(\mathrm{t}), 41.6(\mathrm{~d}), 43.3(\mathrm{t}), 44.2(\mathrm{~d}), 48.0(\mathrm{~d}), 58.9$ (d), $67.8(\mathrm{t}), 69.5(\mathrm{t}), 69.6(\mathrm{t}), 72.7(\mathrm{t}), 94.2(\mathrm{~s}), 124.8(\mathrm{~s}), 126.8(\mathrm{~d}), 129.3(\mathrm{~d}), 138.3(\mathrm{~s})$. Exact mass (CI-HRMS) Calcd for $\mathrm{C}_{27} \mathrm{H}_{33} \mathrm{BrO}_{5}:\left[M_{\mathrm{r}}+\mathrm{H}\right]^{+} \mathrm{m} / \mathrm{z}$ 517.1590. Found: $\left[M_{\mathrm{r}}+\mathrm{H}\right]^{+} \mathrm{m} / \mathrm{z}$ 517.1573. Anal. Calcd for $\mathrm{C}_{27} \mathrm{H}_{33} \mathrm{BrO}_{5}: \mathrm{C}, 62.70 ; \mathrm{H}, 6.50$. Found: $\mathrm{C}, 62.52 ; \mathrm{H}, 6.53$.

Synthesis of podand (13). To a solution of 2-(2-chloroethoxy)ethanol $(630 \mathrm{mg}, 5.0 \mathrm{mmol})$ in dry THF $(100 \mathrm{~mL})$ was added $\mathrm{NaH}(1.20 \mathrm{~g}, 60 \%$ dispersion in mineral oil, $30 \mathrm{mmol})$, and the resulting solution was refluxed under $\mathrm{N}_{2}$ during $3 \mathrm{~h}$. The reaction mixture then was allowed to cool gradually to ambient temperature. To the reaction mixture was added dropwise with stirring a solution of $11^{13}(1.72 \mathrm{~g}, 5.0 \mathrm{mmol})$ in THF $(20 \mathrm{~mL})$ during 30 minutes, and the resulting mixture was refluxed during 3 days. The reaction mixture was allowed to cool gradually to ambient temperature and saturated aqueous $\mathrm{NH}_{4} \mathrm{Cl}$ solution $(40 \mathrm{~mL})$ was added dropwise with stirring to quench the reaction. The resulting mixture was allowed to stand 10 minutes. Two layers were separated; the water layer (bottom layer) was washed with EtOAc $(2 \times 50 \mathrm{~mL})$. The organic layer (upper layer) solvent was dried $\left(\mathrm{MgSO}_{4}\right)$ and filtered. The solvent was concentrated in vacuo, and the residue was dissolved in EtOAc $(100 \mathrm{~mL})$. The combined extracts were washed sequentially with water $(2 \times 100 \mathrm{~mL})$ and brine $(2 \times 100 \mathrm{~mL})$, dried $\left(\mathrm{Na}_{2} \mathrm{SO}_{4}\right)$ and filtered, and the filtrate was concentrated in vacuo. The residue was purified by column chromatography on silica gel by eluting with 40\% EtOAc-hexane. Pure $11(1.81 \mathrm{~g}, 84 \%)$ was thereby obtained as a colorless viscous oil. IR (neat) 2871 (s), 1459 (m), 1450 (m), 1428 (m), 1351 (s), 1298 (s), 1250 (m), 1143 (s), 1104 (s), 1024 (m), $788 \mathrm{~cm}^{-1}(\mathrm{~m}) ;{ }^{1} \mathrm{H} \mathrm{NMR}\left(\mathrm{CDCl}_{3}\right) \delta$ $3.62(\mathrm{t}, J=5.6 \mathrm{~Hz}, 4 \mathrm{H}), 3.72-3.79(\mathrm{~m}, 12 \mathrm{H}), 4.63(\mathrm{~s}, 4 \mathrm{H}), 7.29-7.40(\mathrm{~m}, 3 \mathrm{H}) ;{ }^{13} \mathrm{C}$ NMR $\left(\mathrm{CDCl}_{3}\right) \delta 42.7(\mathrm{t}), 70.1(\mathrm{t}), 70.6(\mathrm{t}), 71.4(\mathrm{t}), 72.8(\mathrm{t}), 122.8(\mathrm{~s}), 127.2(\mathrm{~d}), 128.0(\mathrm{~d}), 137.9(\mathrm{~s})$. Exact mass (CI-HRMS) Calcd for $\mathrm{C}_{16} \mathrm{H}_{23} \mathrm{BrCl}_{2} \mathrm{O}_{5}:\left[M_{\mathrm{r}}+\mathrm{H}\right]^{+} \mathrm{m} / \mathrm{z}$ 428.0157. Found: $\left[M_{\mathrm{r}}+\mathrm{H}\right]^{+}$ $\mathrm{m} / \mathrm{z} 428.0152$.

Synthesis of cage-annulated crown ether (6). To a solution of $\mathbf{1 4} 12$ (496 mg, $2.0 \mathrm{mmol})$ in dry THF (100 mL) was added $\mathrm{NaH}$ (obtained as a 60\% dispersion in mineral oil, $480 \mathrm{mg}, 12 \mathrm{mmol}$ ), 
and the resulting solution was refluxed under $\mathrm{N}_{2}$ during $3 \mathrm{~h}$. The reaction mixture then was allowed to cool gradually to ambient temperature. To the reaction mixture was added dropwise with stirring a solution of $13(1.72 \mathrm{~g}, 5.0 \mathrm{mmol})$ in THF $(20 \mathrm{~mL})$ during 30 minutes, and the resulting mixture was refluxed during 3 days. The reaction mixture was allowed to cool gradually to ambient temperature; subsequently, the stirred reaction mixture was quenched via dropping addition of saturated $\mathrm{NH}_{4} \mathrm{Cl}$ solution $(40 \mathrm{~mL})$. The resulting mixture was allowed to stand 10 minutes, during which time two layers were separated. The water layer (bottom layer) was washed with EtOAc $(2 \times 50 \mathrm{~mL})$. The organic layer (upper layer) solvent was removed in vacuo. The residue was dissolved EtOAc $(100 \mathrm{~mL})$. The combined EtOAc solutions were washed sequentially with water $(2 \times 100 \mathrm{~mL})$ and brine $(2 \times 100 \mathrm{~mL})$, dried $\left(\mathrm{Na}_{2} \mathrm{SO}_{4}\right)$ and filtered, and the filtrate was concentrated in vacuo. The residue was purified by column chromatography on silica gel by eluting with 30\% EtOAc-hexane. Pure 6 (800 mg, 66\%) was thereby obtained as a colorless viscous oil. IR (neat) 2952 (s), 1576 (w), 1451 (m), 1428 (m), $1354(\mathrm{~s}), 1294(\mathrm{~s}), 1112(\mathrm{~s}), 931(\mathrm{~m}), 794 \mathrm{~cm}^{-1}(\mathrm{~m}) ;{ }^{1} \mathrm{H} \mathrm{NMR}\left(\mathrm{CDCl}_{3}\right) \delta 1.32\left(A \mathrm{~B}, J_{\mathrm{AB}}=\right.$ $10.3 \mathrm{~Hz}, 1 \mathrm{H}), 1.67\left(\mathrm{AB}, J_{\mathrm{AB}}=10.3 \mathrm{~Hz}, 1 \mathrm{H}\right), 1.98-2.09(\mathrm{~m}, 8 \mathrm{H}), 3.49-3.79(\mathrm{~m}, 20 \mathrm{H}), 4.63(\mathrm{~s}$, $4 \mathrm{H}), 7.32-7.49(\mathrm{~m}, 3 \mathrm{H}) ;{ }^{13} \mathrm{C} \mathrm{NMR}\left(\mathrm{CDCl}_{3}\right) \delta 32.9(\mathrm{t}), 41.8(\mathrm{~d}), 43.2(\mathrm{t}), 44.4(\mathrm{~d}), 48.2(\mathrm{~d}), 58.8$ $(\mathrm{d}), 68.4(\mathrm{t}), 70.1(\mathrm{t}), 70.2(\mathrm{t}), 70.7(\mathrm{t}), 71.1(\mathrm{t}), 72.5(\mathrm{t}), 94.3(\mathrm{~s}), 122.3(\mathrm{~s}), 127.3(\mathrm{~d}), 127.7(\mathrm{~d})$, 137.9 (s). Exact mass (CI-HRMS) Calcd for $\mathrm{C}_{31} \mathrm{H}_{41} \mathrm{BrO}_{7}:\left[M_{\mathrm{r}}+\mathrm{H}\right]^{+} \mathrm{m} / \mathrm{z}$ 605.2114. Found: $\left[M_{\mathrm{r}}\right.$ $+\mathrm{H}]^{+} \mathrm{m} / \mathrm{z} 605.2113$.

FAAS experiments. The general procedures employed herein are similar to those reported previously. ${ }^{15}$ Thus, solutions of $\mathrm{Ag}_{2} \mathrm{O}(125 \mathrm{mM})$ in $5 \%$ aqueous $\mathrm{HNO}_{3}$ were prepared. No $\mathrm{pH}$ adjustment was required. A $5.0 \mathrm{mM}$ solution of $\mathrm{Ag}(\mathrm{I})$ picrate in $5 \%$ aqueous $\mathrm{HNO}_{3}$ was prepared by placing picric acid $(28.6 \mathrm{mg}, 0.125 \mathrm{mmol}), 5 \%$ aqueous $\mathrm{HNO}_{3}(5 \mathrm{~mL})$, and a $1 \mathrm{~mL}$ aliquot of a $125 \mathrm{mM}$ solution of $\mathrm{Ag}_{2} \mathrm{O}$ in $5 \%$ aqueous $\mathrm{HNO}_{3}$ into a $25 \mathrm{~mL}$ volumetric flask. The resulting mixture was shaken to effect complete dissolution, at which time the resulting solution was diluted to volume $(25.00 \mathrm{~mL})$ via addition of $5 \%$ aqueous $\mathrm{HNO}_{3}$. Chloroform was washed with water to remove EtOH and then was used to prepare $5 \mathrm{mM}$ solutions of each of the hosts to be tested. Aliquots $(0.5 \mathrm{~mL})$ of the $\mathrm{CHCl}_{3}$ solution that contained host compound and the aqueous solution $(0.5 \mathrm{~mL})$ that contained the $\mathrm{Ag}(\mathrm{I})$ picrate were introduced into a screw-topped vial and then were shaken mechanically at ambient temperature during 30 minutes. The resulting mixture was allowed to stand at least 2 hours at ambient temperature in order to effect complete phase separation. A $50 \mu \mathrm{L}$ aliquot was transferred from the aqueous phase of each vial into a $25 \mathrm{~mL}$ volumetric flask and was diluted to volume by addition of $5 \%$ aqueous $\mathrm{HNO}_{3}$.

Atomic absorption measurements of $\operatorname{Ag}(\mathrm{I})$ ion concentrations (ppm) were performed by using a Model 200A Buck Scientific Atomic Absorption Spectrophotometer equipped with a hollow-cathode Ag lamp. Initially, the instrument was calibrated with $5.0 \mathrm{ppm} \mathrm{Cu}$ (II) solution by using a $\mathrm{Cu}$ lamp. Then, standard $\mathrm{Ag}(\mathrm{I})$ solutions $(0.25 \mathrm{ppm}, 0.50 \mathrm{ppm}, 0.75 \mathrm{ppm}, 1.00 \mathrm{ppm}$, $1.25 \mathrm{ppm}$, and $1.50 \mathrm{ppm}$, respectively) were used to complete instrument calibration. Experimental measurements were made in terms of transmittance $(T)$; here, $T=I / I_{O}$, where $I$ is the light intensity after it passes through the sample and $I_{0}$ is the initial light intensity. 
Absorbance, $A$, is related to $T$ by the equation $A=-\log T=-\log (\mathrm{I} / \mathrm{Io})$. Plots of absorbance vs. sample concentration, afforded a straight line, correlation coefficient $r=0.999$.

A control experiment (blank) was performed for the $\mathrm{Ag}(\mathrm{I})$ picrate wherein no host was present in the $\mathrm{CHCl}_{3}$ layer. For each host- $\mathrm{Ag}(\mathrm{I})$ picrate combination, three separate experiments were performed in three separate vials. The percentage of $\mathrm{Ag}(\mathrm{I})$ picrate that had been extracted into the organic phase by a particular host was calculated by using the following equation:

$$
\% \text { extracted }=\left[\frac{(\text { absorbance of blank })-(\text { absorbance of sample })}{(\text { absorbance of blank })}\right] \times 100
$$

\section{Acknowledgments}

We thank the Robert A. Welch Foundation (Grant B-0963), the U. S. Department of Energy (Grant DE-FG07-98ER14936), and the National Science Foundation (Grant CHE-0315337) for financial support of this study.

\section{References}

1. For a review, see: Marchand, A. P.; Kumar, K. A.; McKim, A. S.; Alihodzic, S.; Chong, H.S.; Krishnudu, K.; Takhi, M.; Mlinaric-Majerski, K.; Kragol, G.; Sumanovac, T. Kem. Ind. 2001, 50, 129.

2. (a) Moyer, B. A.; Bonnesen, P. V.; Chambliss, C. K.; Haverlock, T. J.; Marchand, A. P.; Chong, H.-S.; McKim, A. S.; Krishnudu, K.; Ravikumar, K. S.; Kumar, V. S.; Takhi, M. In Nuclear Site Remediation: First Accomplishments of the Environmental Science Program, Eller, P. G.; Heineman, W. R., Eds.; ACS Symposium Series, American Chemical Society: Washington, DC, 2001; Vol. 778, p 114. (b) Levistskaia, T. G.; Moyer, B. A.; Bonnesen, P. V.; Marchand, A. P.; Krishnudu, K.; Chen, Z.; Huang, Z.; Kruger, H. G.; McKim, A. S. J. Am. Chem. Soc. 2001, 123, 12099.

3. Marchand, A. P.; Chong, H.-S.; Ganguly, B. Tetrahedron: Asymmetry 1999, 10, 4695.

4. Paiva, A. P. Sulphur-Nitrogen Ligands in the Solvent Extraction of Silver from Chloride Solutions. Solvent Extraction for the $21^{\text {st }}$ Century; Proceedings of ISEC '99, Barcelona: Spain, July 11-16, 1999, 2001, 399.

5. Herrin, R. T.; Andren, A. W.; Shafer, M.M.; Armstrong, D. E. Environmental Science and Technology 2001, 35, 1959.

6. Wen, M.; Munakata, M.; Suenaga, Y.; Kuroda-Sowa, T.; Maekawa, M. Inorg. Chim. Acta 2002, 332, 18.

7. Williams, S. M.; Brodbelt, J. S.; Huang, Z.; Lai, H.; Marchand, A. P. Analyst Manuscript submitted 2003. 
8. Marchand, A. P.; Chong, H.-S.; Alihodzic, S.; Watson, W. H.; Bodige, S. G. Tetrahedron 1999, 55, 9687.

9. Marchand, A. P.; Cal, D.; Mlinaric-Majerski, K.; Ejsmont, K.; Watson, W. H. J. Chem. Crystallogr. 2002, 32, 447.

10. Li, Z. T.; Zhang, X. L.; Lain, X. D.; Yu, Y. H.; Xia, Y.; Xia, Y.; Zhao, C. X.; Chen, Z.; Lin, Z. P.; Chen, H. J. Org. Chem. 2000, 65, 5136.

11. Oepen, G.; Dix, J. P.; Vögtle, F. Justus Liebigs Ann. Chem. 1978, 1592.

12. Marchand, A. P.; Kumar, K. A.; McKim, A. S.; Mlinaric-Majerski, K.; Kragol, G. Tetrahedron 1997, 53, 3467.

13. Fujihara, H.; Chiu, J. J.; Furukawa, N. Chem. Lett. 1991, 141.

14. (a) Pedersen, C. J. Fed. Proc., Fed. Am. Soc. Exp. Biol. 1968, 27, 1305. (b) Lamb, J. D.; Izatt, R. M.; Christensen, J. J. Progress in Macrocyclic Chemistry; Izatt, R. M.; Christensen, J. J., Eds; Wiley: New York, 1981. (c) Hancock, R. D.; Martell, A. E. Chem. Rev. 1989, 89, 1875.

15. Test Methods for Evaluating Solid Waste, Physical/Chemical Methods (SW-846); U. S. Government Printing Office: Washington, D. C. 20402, Publication Number: 955-00100000-1, $3^{\text {rd }}$ Ed; 1995; Vol. IA, Ch. 3, Section 3.3. 